\title{
Already dependent: a dependency analysis of market activity on tin mining in Bangka Belitung
}

\author{
Ibrahim Ibrahim ${ }^{1, *}$, Dwi Haryadi ${ }^{2}$, and Nanang Wahyudin ${ }^{1}$ \\ ${ }^{1}$ Political Science Department, Bangka Belitung University, Indonesia \\ ${ }^{2}$ Law Department, Bangka Belitung University, Indonesia \\ ${ }^{3}$ Management Department, Bangka Belitung University, Indonesia
}

\begin{abstract}
Tin in Bangka Belitung has been exploited since 17th century; however, local people have received the opportunity in mining only in the last two decades, when the tin was not set as a state's strategic commodity. Therefore, since the last two decades, people economic activities in this area have dramatically increased. Nevertheless, it was not as long as two decades that tin had its glory. The tin price fluctuated along with its production. However, in turn, the market has already been dependent on tin mining. Through the qualitative study having survey motive, this paper traced the answer of the key question: "Is it true that Bangka Belitung economy is a tin economy?" This study was performed in a market area selling people's primary and tertiary needs in all regions and municipalities of Bangka Belitung Islands Province. It concluded that market dependency on tin mining was extremely high. Market has had a direct impact on the price increase and decrease of tin mining and its production. It also inferred that at least the tin mining and trader were in the same condition in that they were very depended on tin commodity. This was a consequence of the motivation of the economy from which it was initially independent, and it was at this time that it became dependent, and it was difficult to get out of this dependence. This condition was called as already dependent.
\end{abstract}

\section{Introduction}

Bangka Belitung Islands Province, Indonesia, basically depend its people's economy life on natural resources exploitation. There are at least three major economy resources for the people in this area: plantation, marine and fishery, and tin mining sector. The latest has just actually occurred in the last two decades. Though tin mining activities in the islands have been long lasted; however, the society has just directly mined after the regulation was issued. Before tin was allowed to be freely exploited, tin production was controlled by two major companies under the strict rule from the government.

In 1998, central government revoked the regulation of tin commodity into the one being not regulated and monitored by the state [1]. Since then, its implication was the mushrooming of people mining in which it was usually illegal mining [2;3]. Related to terminology, 'illegal' is actually debatable [4] as the central government itself doesn't

\footnotetext{
*Corresponding author: iim_babel@yahoo.com
} 
clearly rule tin mining operated by society, unless for the mining prohibition in protected forest and watershed. More precisely is that government has restrained its authority in tin management arrangement since it was not stipulated as strategic commodity by central government.

Bangka Belitung itself is islands area well known worldwide through its tin production [5-8]. This area has recently been the only tin producer in Indonesia and Southeast Asia territory. It can be ascertained that tin production in South East Asia region comes from Bangka Belitung, in which with some ways it can come and circulate in international market. As an area rich with tin resources, since tin production was not monopolized by two major companies as only did in New Order era and first decade of Reform Order [9], people has made tin as an excellent.

People economy development can directly be felt since tin has been freely mined by society, both in land and off-shore. In an area of 16.424.23 square kilometers with its 79.9 $\%$ is ocean [10], it has been estimated that there are thousands of tin miners working every day in Bangka Belitung. They are generally the miners without license and ignoring the principles of friendly environment mining [11-13]. Local people economy life rapidly increased signed by people's consumption changing on luxurious and tertiary goods, increased income per capita, and indeed, signed by the increasing of population inflow numbers from outside area into this island. There was at least statistical number showing that mining profession is the most dominant job in this area [10].

This study departed from a key question on how actually the tin effect toward market activities, both traditional and semi-modern in this area. Market in this study is translated as an arena to sell basic necessity and tertiary good in a more simple meaning, rather than a market in a macro context. Market in this local terminology has more physical nature and directly activating. Why is market important? Since as some people annunciated Bangka Belitung economy was much depended on tin mining activity, it is the market activities that become one of its simple indicators. It would be then whether or not the tin price fluctuation along with its production influences people's purchasing power. This study had chosen market traders in all regencies/municipalities in this island province to ensure that Bangka Belitung people economy is indeed much determined by tin.

\section{Material and Method}

This study was designed using quantitative approach in a form of survey. The study instrument used was 16 closed question list in likert scale. The population study was traders in some big markets in every regency and municipality capital in Bangka Belitung Islands Province. The intended big markets are the biggest one in the region, in this case, it has census characteristic having study location in 7 areas, Koba market in Central Bangka, Toboali market in south Bangka, Mentok market in west Bangka, Sungailiat market in Bangka, Tanjung Pandan market in Belitung, Manggar market in east Belitung, and BTC market, Morning market, Jendral Sudirman street and Koba street in Pangkal Pinang. The respondents interviewed were the traders who have been estimated to trade for more or less 10 years by considering that they have known and felt much about trading dynamics from time to time. This survey itself was conducted on October 2018.

This study employed non-probability sampling having quota sampling procedure. Quota sampling itself is a sampling collection by considering the similar proportion [14]. The number of respondents in each regency was set as 50 people, while in consideration as an urban area as well as a capital province, Pangkal Pinang would have 120 respondents. Total respondents in this study were 420. Respondent determination was not rigidly defined, except for evenly distribution among five trading types: clothing, food, housing, electrical appliances, and car/motorcycle trader. Since the first respondent determination, it was 
organized that a respondent should minimally have one location garden bed distance from the previous one. As for data analysis used was descriptive data in support of SPSS 20 program.

\section{Result}

\subsection{Respondent Identity}

Based on the research method used, respondent identity was presented in the following table:

Table 1. Respondent distribution based on survey area.

\begin{tabular}{|l|l|c|c|}
\hline \multicolumn{2}{|c|}{} & Frequency & Percent \\
\hline Valid & Pangkal Pinang & 120 & 28.6 \\
\cline { 2 - 4 } & Bangka & 50 & 11.9 \\
\cline { 2 - 4 } & Central Bangka & 50 & 11.9 \\
\cline { 2 - 4 } & South Bangka & 50 & 11.9 \\
\cline { 2 - 4 } & West Bangka & 50 & 11.9 \\
\cline { 2 - 4 } & Belitung & 50 & 11.9 \\
\cline { 2 - 4 } & East Belitung & 50 & 11.9 \\
\cline { 2 - 4 } & Total & 420 & 100.0 \\
\hline
\end{tabular}

Table 2. Respondent distribution based on survey area location point.

\begin{tabular}{|l|l|c|c|}
\hline \multicolumn{2}{|c|}{} & Frequency & Percent \\
\hline Valid & Pembangunan Market & 30 & 7.1 \\
\cline { 2 - 4 } & Pagi Market & 30 & 7.1 \\
\cline { 2 - 4 } & Trader on Jalan Utama I & 30 & 7.1 \\
\cline { 2 - 4 } & Trader on Jalan Utama II & 30 & 7.1 \\
\cline { 2 - 4 } & Sungai Liat Market & 50 & 11.9 \\
\cline { 2 - 4 } & Mentok Market & 50 & 11.9 \\
\cline { 2 - 4 } & Toboali Market & 50 & 11.9 \\
\cline { 2 - 4 } & Koba Market & 50 & 11.9 \\
\cline { 2 - 4 } & Tanjung Pandan Market & 50 & 11.9 \\
\cline { 2 - 4 } & Manggar Market & 50 & 11.9 \\
\cline { 2 - 4 } & Total & 420 & 100.0 \\
\hline
\end{tabular}

Table 3. Respondent distribution based on ethnic.

\begin{tabular}{|l|l|c|c|}
\hline \multicolumn{2}{|c|}{} & Frequency & Percent \\
\hline Valid & Malay & 180 & 42.9 \\
\cline { 2 - 4 } & Tionghoa & 221 & 52.6 \\
\cline { 2 - 4 } & Other & 19 & 4.5 \\
\cline { 2 - 4 } & Total & 420 & 100.0 \\
\hline
\end{tabular}

Table 4. Respondent distribution based on the origin of the item type traded.

\begin{tabular}{|c|c|c|c|}
\hline \multirow{2}{*}{\begin{tabular}{|l|} 
\\
Valid
\end{tabular}} & \multirow[b]{2}{*}{\begin{tabular}{|l|} 
Clothing \\
\end{tabular}} & \multirow{2}{*}{$\begin{array}{c}\text { Frequency } \\
91\end{array}$} & \multirow{2}{*}{$\begin{array}{l}\text { Percent } \\
21.7\end{array}$} \\
\hline & & & \\
\hline & Food & 93 & 22.1 \\
\hline & Housing & 79 & 18.8 \\
\hline & $\begin{array}{l}\text { Electrical - } \\
\text { Appliances }\end{array}$ & 80 & 19.0 \\
\hline & Car/Motorcycle & 77 & 18.3 \\
\hline & Total & 420 & 100.0 \\
\hline
\end{tabular}


Based on Table 1, it can be seen that except for Pangkal Pinang, six other regencies in this province, each of it had similar number of respondents. Pangkal Pinang itself had more quotas by considering that it is the crowd center in this province. In addition as the only region administratively called as municipality, Pangkal Pinang is also a capital city of Bangka Belitung Islands Province. Meanwhile, Table 2. showed that there were 10 survey location points, 4 of them were BTC, Morning Market, Jendral Sudirman street, and Koba street. While 6 other points were regency centers; Sungailiat, Mentok, Toboali, Koba, Tanjung Pandang, and Manggar.

The majority of respondents were respectively Tionghoa, Malay, and other ethnics as presented in Table 3. Markets in Bangka Belitung are generally dominated by Tionghoa ethnic. It is the ethnical diaspora coming from China mainland and entering to Bangka Belitung in waves in colonial era. Meanwhile, based on Table 4, it can be seen that respondents were generally divided into almost evenly in five item cluster sold, they were clothing, food, housing, electrical equipment, and motorcycle/car.

\subsection{Frequency Table Result}

Table 5. Tin price fluctuation would influence commodity buying and selling activity

\begin{tabular}{|c|l|c|c|}
\hline \multicolumn{2}{|l|}{ Valid } & Frequency & Percent \\
\cline { 2 - 4 } & Totally Disagree & 4 & 1.0 \\
\cline { 2 - 4 } & Disagree & 39 & 9.3 \\
\cline { 2 - 4 } & Not Knowing & 22 & 5.2 \\
\cline { 2 - 4 } & Agree & 177 & 42.1 \\
\cline { 2 - 4 } & Totally Agree & 178 & 42.4 \\
\cline { 2 - 4 } & Total & 420 & 100.0 \\
\hline
\end{tabular}

Table 6. Tin price fluctuation would directly influence (at once) community spending ability.

\begin{tabular}{|c|l|c|c|}
\hline \multicolumn{2}{|c|}{} & Frequency & Percent \\
\hline Valid & Totally Disagree & 3 & .7 \\
\cline { 2 - 4 } & Disagree & 45 & 10.7 \\
\cline { 2 - 4 } & Not Knowing & 23 & 5.5 \\
\cline { 2 - 4 } & Agree & 184 & 43.8 \\
\cline { 2 - 4 } & Totally Agree & 165 & 39.3 \\
\cline { 2 - 4 } & Total & 420 & 100.0 \\
\hline
\end{tabular}

Table 7. It can be said that Bangka Belitung economy would be greatly depended on tin commodity.

\begin{tabular}{|c|l|c|c|}
\hline \multicolumn{1}{|c|}{} & Frequency & Percent \\
\hline Valid & Totally Disagree & 2 & .5 \\
\cline { 2 - 4 } & Disagree & 68 & 16.2 \\
\cline { 2 - 4 } & Not Knowing & 67 & 16.0 \\
\cline { 2 - 4 } & Agree & 160 & 38.1 \\
\cline { 2 - 4 } & Totally Agree & 123 & 29.3 \\
\cline { 2 - 4 } & Total & 420 & 100.0 \\
\hline
\end{tabular}

Table 8. Recent selling level is lower than that in tin glory era

\begin{tabular}{|c|l|c|c|}
\hline \multicolumn{1}{|c|}{} & Frequency & Percent \\
\hline Valid & Totally Disagree & 2 & .5 \\
\cline { 2 - 4 } & Disagree & 36 & 8.6 \\
\cline { 2 - 4 } & Not Knowing & 31 & 7.4 \\
\cline { 2 - 4 } & Agree & 185 & 44.0 \\
\cline { 2 - 4 } & Totally Agree & 166 & 39.5 \\
\cline { 2 - 4 } & Total & 420 & 100.0 \\
\hline
\end{tabular}


Table 9. There are some differences on society purchasing ability from one period to the next one.

\begin{tabular}{|c|l|c|c|}
\hline \multicolumn{2}{|c|}{} & Frequency & Percent \\
\hline Valid & Totally Disagree & 2 & .5 \\
\cline { 2 - 4 } & Disagree & 27 & 6.4 \\
\cline { 2 - 4 } & Not Knowing & 32 & 7.6 \\
\cline { 2 - 4 } & Agree & 225 & 53.6 \\
\cline { 2 - 4 } & Totally Agree & 134 & 31.9 \\
\cline { 2 - 4 } & Total & 420 & 100.0 \\
\hline
\end{tabular}

Table 10. Middle to lower level group has been very affected to tin price.

\begin{tabular}{|c|l|c|c|}
\hline \multicolumn{2}{|c|}{ Valid } & Frequency & Percent \\
\cline { 2 - 4 } & Totally Disagree & 2 & .5 \\
\cline { 2 - 4 } & Disagree & 31 & 7.4 \\
\cline { 2 - 4 } & Not Knowing & 65 & 15.5 \\
\cline { 2 - 4 } & Agree & 200 & 47.6 \\
\cline { 2 - 4 } & Totally Agree & 122 & 29.0 \\
\cline { 2 - 4 } & Total & 420 & 100.0 \\
\hline
\end{tabular}

Table 11. The buyers whose profession is miner or miner's family generally come from village.

\begin{tabular}{|c|l|c|c|}
\hline \multicolumn{2}{|c|}{} & Frequency & Percent \\
\hline Valid & Totally Disagree & 2 & .5 \\
\cline { 2 - 4 } & Disagree & 25 & 6.0 \\
\cline { 2 - 4 } & Not Knowing & 41 & 9.8 \\
\cline { 2 - 4 } & Agree & 213 & 50.7 \\
\cline { 2 - 4 } & Totally Agree & 139 & 33.1 \\
\cline { 2 - 4 } & Total & 420 & 100.0 \\
\hline
\end{tabular}

Table 12. Tin price downturn impact would largely pervade to other sectors.

\begin{tabular}{|c|l|c|c|}
\hline \multicolumn{2}{|l|}{} & Frequency & Percent \\
\hline Valid & Totally Disagree & 1 & .2 \\
\cline { 2 - 4 } & Disagree & 34 & 8.1 \\
\cline { 2 - 4 } & Not Knowing & 63 & 15.0 \\
\cline { 2 - 4 } & Agree & 203 & 48.3 \\
\cline { 2 - 4 } & Totally Agree & 119 & 28.3 \\
\cline { 2 - 4 } & Total & 420 & 100.0 \\
\hline
\end{tabular}

Table 13. People economy will be challenging if tin is not the excellent anymore.

\begin{tabular}{|c|l|c|c|}
\hline \multicolumn{2}{|c|}{} & Frequency & Percent \\
\hline Valid & Totally Disagree & 1 & .2 \\
\cline { 2 - 4 } & Disagree & 66 & 15.7 \\
\cline { 2 - 4 } & Not Knowing & 87 & 20.7 \\
\cline { 2 - 4 } & Agree & 159 & 37.9 \\
\cline { 2 - 4 } & Totally Agree & 107 & 25.5 \\
\cline { 2 - 4 } & Total & 420 & 100.0 \\
\hline
\end{tabular}

Table 14. If tin economy is getting downturn, respondent's selling may be directly impacted.

\begin{tabular}{|c|l|c|c|}
\hline \multicolumn{2}{|c|}{} & Frequency & Percent \\
\hline Valid & Totally Disagree & 2 & .5 \\
\cline { 2 - 4 } & Disagree & 69 & 16.4 \\
\cline { 2 - 4 } & Not Knowing & 34 & 8.1 \\
\cline { 2 - 4 } & Agree & 187 & 44.5 \\
\cline { 2 - 4 } & Totally Agree & 128 & 30.5 \\
\cline { 2 - 4 } & Total & 420 & 100.0 \\
\hline
\end{tabular}


Table 15. If the economic downturn as a result of tin price decreased keeps continuing, perhaps respondent will find other alternatives.

\begin{tabular}{|c|l|c|c|}
\hline \multicolumn{2}{|c|}{} & Frequency & Percent \\
\hline Valid & Totally Disagree & 14 & 3.3 \\
\cline { 2 - 4 } & Disagree & 196 & 46.7 \\
\cline { 2 - 4 } & Not Knowing & 63 & 15.0 \\
\cline { 2 - 4 } & Agree & 89 & 21.2 \\
\cline { 2 - 4 } & Totally Agree & 58 & 13.8 \\
\cline { 2 - 4 } & Total & 420 & 100.0 \\
\hline
\end{tabular}

Table 16. Respondent knows that tin based economy will undermine environment.

\begin{tabular}{|c|l|c|c|}
\hline \multicolumn{2}{|c|}{ Valid } & Frequency & Percent \\
\cline { 2 - 4 } & Not Knowing & 4 & 1.0 \\
\cline { 2 - 4 } & Agree & 26 & 6.2 \\
\cline { 2 - 4 } & Totally Agree & 212 & 50.5 \\
\cline { 2 - 4 } & Total & 420 & 42.4 \\
\hline
\end{tabular}

Table 17. Tin mining provided more benefit to outsider than that directly to the local community.

\begin{tabular}{|c|l|c|c|}
\hline \multicolumn{2}{|c|}{} & Frequency & Percent \\
\hline Valid & Totally Disagree & 4 & 1.0 \\
\cline { 2 - 4 } & Disagree & 58 & 13.8 \\
\cline { 2 - 4 } & Not Knowing & 113 & 26.9 \\
\cline { 2 - 4 } & Agree & 140 & 33.3 \\
\cline { 2 - 4 } & Totally Agree & 105 & 25.0 \\
\cline { 2 - 4 } & Total & 420 & 100.0 \\
\hline
\end{tabular}

Table 18. Respondent will support if government firmly forbids tin mining among societies.

\begin{tabular}{|c|l|c|c|}
\hline \multicolumn{2}{|c|}{} & Frequency & Percent \\
\hline Valid & Totally Disagree & 11 & 2.6 \\
\cline { 2 - 4 } & Disagree & 120 & 28.6 \\
\cline { 2 - 4 } & Not Knowing & 124 & 29.5 \\
\cline { 2 - 4 } & Agree & 84 & 20.0 \\
\cline { 2 - 4 } & Totally Agree & 81 & 19.3 \\
\cline { 2 - 4 } & Total & 420 & 100.0 \\
\hline
\end{tabular}

\section{Discussion}

\subsection{Tin fluctuation, market fluctuation}

Based on the survey result data as shown in Table 5, most traders stated as agree on the statement that 'tin price greatly influences the buying-selling activities of traded commodity. More or less $42.4 \%$ revealed to be totally agree and $42.1 \%$ expressed as agree. It means more or less $84.5 \%$ expressed their agreement on this condition. Indeed, tin price fluctuation also correlated to tin production produced by miners.

Visually, tin price and production capacity fluctuation produced by miners actually influenced market activities much. As the tin price and mining increased, market itself would be seen as active. Researchers' observation found such condition. The question would be then, "Is the influence directly perceived?" In this statement, $43.6 \%$ and $39.3 \%$ as shown in data of Table 6 expressed its agreement. In other word, the fluctuation was directly felt at once. Therefore, it can be said that the income in tin sector directly influenced people's purchasing ability. The tin dependency in Bangka Belitung people 
could thus be said as high. It was not surprising, when one was asked to conclude as shown in Table 7 whether it could be said that Bangka Belitung people's economy was depended on tin commodity, the answer would be then more or less $67.4 \%$. Although this number decreased in terms of statement on tin dependency, the fact was that most people expressed their agreement.

Meanwhile, as a trader who has experienced quite long phase in market activities, regarding that one of inclusion criteria for respondent was determined by more than 10 years in selling, thus $83.5 \%$ on Table 8 . revealed their agreement on the current selling level statement in which it is truly lower than the tin glorious era in the early 2000 . This condition affirmed the tin influence toward daily market activities directly visited by society. The interesting thing was that from one period to the other, there was difference among society purchasing capacity as represented in Table 9 . Tin price fluctuation could be occurred within one phase having duration of 2, 3 year or more. Some $53.6 \%$ stated as agree, and $31.9 \%$ revealed as totally agree. It could be said that $85.5 \%$ respondent expressed their agreement on this statement.

Who would get affected then? Middle to lower group? More or less $47.6 \%$ revealed as agree and $29 \%$ stated as totally agree. Table 10. represented it. Simply said, there was about $76.6 \%$ expressed it in middle to lower group. Among them, $15.5 \%$ asserted the hesitance. This data showed that there was basically a strong influence toward middle to lower group on tin mining activities, this could be at least measured from the traders' prespective whose daily activities are facing community spending ability.

Unique information was presented by this data regarding the one as 'Do those having profession as miner come from the village or not?' Table 11 confirmed that $83.8 \%$ respondents stated as 'yes', in which most miners came from village. Which village? Villages from out of town and they do generally the mining area. It means that miners were relatively directly connected to their consumption as the tin was in its price and production triumphant. Where did they know about it? It was certainly through their interactions. Language and the way they communicate could easily show their origin. This data confirmed that indeed the areas rich with tin widely spread from suburbs and far from down town.

How was the downturn impact of tin mining activity toward other sectors then? As already known that Bangka Belitung is a small area and in an islands form. This region also depends on tin commodity and thus the effect will certainly be felt. The majority of respondents $(76.3 \%)$ as in Table 12 answered that other sectors would get the effect. In this case, they are service sector, industry, tourism sector, and others. It was then how its effect toward the community economy in general. Although the number was not high, however most of them believed that tin which was no longer excellent would also influence the community economy in general. Some $63.4 \%$ believed that, while $20.7 \%$ of them doubtly answered as shown in Table 13.

In the statement trying to measeure miner's personal expectation and attitude, it was found an interesting data. Some $75 \%$ respondents revealed that they were agree and totally agree on the statement regarding that tin economy downturn would directly affect their selling business units. This could be seen in Table 14. The interesting however was when it was asked if the economy crisis as a result of tin price and production downturn continuing would they think other alternative livelihood, $50 \%$ of them answered totally disagree and disagree, only $35 \%$ stated as they would change to other sector, while $15 \%$ of them had hesitate attitude. This was shown in Table 15.

Another interesting data was presented in Table 16. It tested the question whether they knew or not if mining activity would destroy the environment. Among of them, $92.9 \%$ said agree and totally agree. They were also aware that tin mining activities generally provide more benefit to outsider rather than directly to local people. According to Table 17., $58.3 \%$ 
of them were agree and totally agree to this statement, and $26.9 \%$ of them answered in hesitant. The unique was that on statement whether they would support the government or not if it decisively forbid tin mining directly operated by community; the answer was distributed between, agree, hesitant, and disagree. Among them, $39.3 \%$ answered agree/totally agree, $31.2 \%$ revealed as disagree/totally disagree, and $29.5 \%$ of them answered in hesitant. This data was presented in Table 18.

\subsection{Tin economy: the dependency already occurred}

The adherents of dependency theory since long time ago have realized that poverty, backwardness, and the lagging behind for underdeveloped and developing countries are not the result of internally inherent structure, but because there is trapping situation from outside and thus it is difficult for the poor and the back warder to move out from poverty trap $[15 ; 16]$. It is widely known that political and economic structure for the underdeveloped countries are generally influenced by economic structure tending to be exploitative, depends on natural resources, and usually have poor technology capacity, human resource capacity, and in turn poor in financial $[17 ; 18 ; 19 ; 20 ; 21]$.

This study would be valid evidence that dependency often raised as either truly designed in upstream level or it really emerged as a natural trap. It shows that in a very small realm, dependency would emerge both as a part of capitalistic economy structure and short term profit oriented. This study was an upstream face of the working mechanism for dependency theory generally known to explain why there remain many poor areas though they are basically rich with its natural resources.

Survey result data to test the key question on 'is it true that Bangka Belitung economy is actually tin based' showed the convincing answer that exploitative development motive would only result in dependency. This study showed that Bangka Belitung economy in the last two decades has deserved to be tin economy; an economic motive greatly depended on tin production and price.

There were at least some very dependant elements. First, it was the seller dependency toward the mining activity they worked in, either directly or as its trading activity in lower level. As the tin price increased and tin production improved, then market activity would be directly active, and vice versae. This fluctuation took place with a different rhythm in one cycle during the last two decades. The next question would be then "How would be the society fate whose living cost and other needs were very dependent on tin activities?" Using their own logic, there was a need to offset their life needs through switching over their livelihood that could be ensured as not running smoothly. Natural dependency is the miner's characteristic attaching the meaning as not having skill other than selling the power for the sake of exploiting other.

The second element was the traders' dependency. This survey result data showed that market traders were trapped in tin price fluctuation. Initially, the trade activities at the beginning of the last two decades naturally ran and relatively stable. Mining activities that had created economic income explosion shoved the trade into more boisterous. The mining glory era had certainly enjoyed through a set of business unit development, however along with tin fluctuation, then the economic activity experienced shock and had real impact on their income. This study found that the traders admitted as widely affected by tin economic unstable condition. Tragically, they generally decided to not shifting their business units. It means that dependency headed into a dim phase as the tin kept decreasing that would accompany their journey. This condition was perceived by the author as a trap on tin management design having orientation in exploitative condition.

The traders also convincingly answered that tin mining already leveraging market activities basically destroyed environment. They were aware themselves that the tin mining 
they operated damaging the environment (Ibrahim, et.al, 2018). When proposing a question, however, whether the mining should be strictly prohibited, the traders themselves were not in one agreement and they tended to express their disagreement, although it was not significantly stated. It means that in addition to economic dependency trap, there also came up ecological attitude dependency on the income gained.

This dependency is basically the one that cannot be rectified; an already occurred dependency; therefore, the author prefered to refer it as 'already dependent'. Since the central government still put tin as a state strategic commodity, Bangka Belitung local people made a distance and didn't involve in tin mining activity. At that time, local economy relied on plantation and fishery sectors. Deregulation and privatization, however, have pushed the shifting into dependency. Recently, after two decades running, as the tin has walked away along with the awareness to start arrange that already occurred, everything has been almost late. The miners have already trapped in a difficult condition, between shifting and continuing profession in a juridically and ecologically not conducive condition, while the traders find difficulties to return to pursue the condition before the last two decades.

Borrowing Gunder Frank's terminology that exploitative development in a rich natural resources country will only bear dependency. The fact that this study found a dependency that was difficult to cure. Although recently, tin keep continuously exploited, its charm continue to decline, while its dependency will keep inclining. Of course, it is not a mutual benefit dependency, but it is an adverse dependence to local peole. As this dependency continuously occurred, the important question would be then "who will be the one mostly enjoying the tin flow that keeps drifting into international market and how to recover the dependency that already happened? Two decades run fast, in fact, it brings forth a long dependency.

In this study context, the real issue became simple: that there was acute dependency between market activity and tin mining operated by small people. This dependency has already been dependant. How to overcome the dependency, the answer however would not be simple. Gradually, the dependency that initially was still simple would bring forth the more complicated condition. Meanwhile, the dependency would be more unaware, as the miners and traders still operated on the initial dependency: a condition where tin was getting difficult and influenced miners' spending ability, while the traders depended their income on the fluctuative tin price and production.

\section{Conclusions}

This study deduced that selling activities in primary markets available in Bangka Belitung Islands Province were greatly depended on tin mining results. Tin mining was bound in price and production definition. Respondent generally admitted and realized that Bangka Belitung economy was the one depended on tin mining activities. Tin price fluctuation impact would be at once, for example, directly influenced activities in the market.

This study also found that traders were affected to unstable tin economy condition. Respondents were worried that this would give impact to other sectors. Interestingly, although affected, respondents generally didn't plan to switch their jobs, though they were also aware that tin economy basically destroyed environment. They also generally realized that tin mining basically more affected middle to lower level society and provided more benefit to outsiders; however, they were generally disagree if mining by common people was forbidden by government.

This condition brought forth to what was known as dependency, an already occurred dependency to tin. Basically, an already occurred dependency directly targeted miners and the traders themselves. Although there was an option as not mining anymore, in fact, the 
market economy was greatly determined by the income from mining. While for traders, the fate of income stability as a result of tin mining situation instability could not convince them to switch to other sectors. This condition explained that exploitative economy would in turn only bring forth dependency.

\section{References}

1. Belitung, Indonesia, International Journal of Social Sciences 4(1), 360-382 (2018)

2. B. Yunianto, Journal of Mineral and Coal 5(3) (2009)

3. J. Susilo, S. Maemunah, Three Centuries of Serving The World : Tin Mining Portrait in Bangka Belitung (Mining Advocation Networking-JATAM, Jakarta, 2009)

4. R.R. Irawan, R. Rudy, International Journal of Business and Management Review 2(3), 48-58 (2014)

5. S. Sujitno, The Impact of Indonesian Tin Throughout History (Jakarta, Gramedia Pustaka Utama, 2007)

6. M.F. Heidhues, Bangka Tin, Mentok Pepper, Chinese People Role in 18th to 20th Century Bangka Island Development (Jakarta, Yayasan Nabil, 2008)

7. E. Erman, Journal of Indonesian Society, Edition XXVI 2, 71-101 (2010)

8. A. Supriadi, Analysis of Price Formation in Indonesian and World Tin Exchange, The Data Center and Information Technology, Energy, and Mineral Resources (Jakarta, Ministry of Energy and Mineral Resources, 2016)

9. I. Ibrahim, GSTF Journal of Law and Social Sciences 5(1), 1-7 (2016)

10. BPS (Badan Pusat Statistik) Provinsi Kepulauan Bangka Belitung, Region Statisitc of Bangka Belitung Islands Province Year 2018 (2018)

11. E. Erman, From Kampong Formation to Dark Problem, Uncover Tin History in Bangka Belitung (Ombak, Yogyakarta, 2009)

12. B. Rahman, Tin Problem in Babel (Several Stories and Ideas) (Yogyakarta, Khomza, 2011)

13. D. Haryadi, Illegal Tin Mining (Life Time Problem?), After 14 years (The Journey Note of Bangka Belitung Islands Province) (Yogyakarta, Imperium, 2014)

14. L. Harrison, Methodology of Political Studies (Jakarta, Kencana, 2016)

15. V. Ferraro, Dependency Theory: An Introduction (Mount Holyoke College South Hadley, MA, 1996)

16. P. Rianto, Globalisation, Economic Liberalization, and The Crisis of Democracy, in Critics of Globalisation and Neoliberalism (Yogyakarta, FISIPOL UGM, 2006)

17. A. Budiman, Development Theory of The Third World (Jakarta, PT. Gramedia Pustaka Utama, 1995)

18. F.A. Samekto, Capitalism, Modernization, and Environmental Damage (Yogyakarta, Genta Press, 2008)

19. Y. Umarhadi, The Trap of Liberalization, Pragmatism, Foreign Domination, and The Dependency of Indonesia Economic (Yogyakarta, Cakrawala Institute, 2010)

20. R. Abrahamsen, The Dark Corner of Development, Power Relation in Development Issues (Yogyakarta, Lafadl Pustaka, 2004)

21. I. Rosyida, W. Khan, M. Sasaoka, Journal of The Extractive Industries and Society 5, 165-176 (2018) 